\title{
Personality characteristics and labour market entry : an exploration
}

Citation for published version (APA):

Semeijn, J. H., Boone, C. A. J. J., \& van der Velden, R. K. W. (2000). Personality characteristics and labour market entry : an exploration. Researchcentrum voor Onderwijs en Arbeidsmarkt, Faculteit der Economische Wetenschappen. ROA Research Memoranda No. 1E https://doi.org/10.26481/umaror.200001E

Document status and date:

Published: 01/01/2000

DOI:

10.26481/umaror.200001E

Document Version:

Publisher's PDF, also known as Version of record

\section{Please check the document version of this publication:}

- A submitted manuscript is the version of the article upon submission and before peer-review. There can be important differences between the submitted version and the official published version of record.

People interested in the research are advised to contact the author for the final version of the publication, or visit the DOI to the publisher's website.

- The final author version and the galley proof are versions of the publication after peer review.

- The final published version features the final layout of the paper including the volume, issue and page numbers.

Link to publication

\footnotetext{
General rights rights.

- You may freely distribute the URL identifying the publication in the public portal. please follow below link for the End User Agreement:

www.umlib.nl/taverne-license

Take down policy

If you believe that this document breaches copyright please contact us at:

repository@maastrichtuniversity.nl

providing details and we will investigate your claim.
}

Copyright and moral rights for the publications made accessible in the public portal are retained by the authors and/or other copyright owners and it is a condition of accessing publications that users recognise and abide by the legal requirements associated with these

- Users may download and print one copy of any publication from the public portal for the purpose of private study or research.

- You may not further distribute the material or use it for any profit-making activity or commercial gain

If the publication is distributed under the terms of Article $25 \mathrm{fa}$ of the Dutch Copyright Act, indicated by the "Taverne" license above, 


\title{
Personality Characteristics and Labour Market Entry an exploration
}

\author{
ROA-RM-2000/1E
}

Judith Semeijn*, Rolf van der Velden* and Christophe Boone ${ }^{* *}$

* $\quad$ Research Centrum voor Onderwijs en Arbeidsmarkt (ROA; in English, Research Centre for Education and the Labour Market)

** Department of Management Sciences, and Netherlands Institute of Business Organization and Strategy Research (NIBOR)

Research Centre for Education and the Labour Market

Faculty of Economics and Business Administration

Maastricht University

Maastricht, August 2000 
ISBN 90-5321-289-2

Sec00.137/JS 


\section{Contents}

Page

Summary

i

1 Introduction 1

2 Theoretical background 2

2.1 Locus of control 3

2.2 Type A behaviour 4

2.3 Self-monitoring $\quad 4$

2.4 Sensation seeking 5

3 Methodology 5

4 Results $\quad 8$

5 Conclusions and considerations 12

References 13

$\begin{array}{ll}\text { Appendix } & 17\end{array}$ 



\section{Summary}

In an explorative study, the value of four personality constructs in predicting success in the labour market entry has been analysed with a sample of graduates in economics from Maastricht University. The research question is: do personality characteristics predict labour market entry success and how much weight do these 'soft' factors have compared to the traditional 'hard' human capital factors like study results? Two out of the four constructs, i.e. (internal) Locus of control and Type A behaviour appear to have a positive effect on labour market success. The effects are independent of the effects of study results and other traditional human capital variables. Locus of control affects getting a job soon after graduation and having tenure, whereas Type A behaviour affects having tenure and wages. Study results merely affect job quality indicators. For obtaining an academic job, the human capital factors have a positive effect while personality has no effect at all. The findings underline the relevance of further labour market research with respect to the importance and role of the so called 'soft' factors like personality characteristics. At the same time, the role of 'hard' human capital factors is not to be neglected. Both types of factors seem to have their own and independent effects. Future research directions are given and implications of the study are discussed.

JEL-code: j24

Keywords: personality, labour market success. 



\section{Introduction}

Due to technological developments and the expanding international orientation of many organizations, labour market demands have changed. Traditional 'hard' selection devices like educational background still count, but are not sufficient anymore. Many argue that individual, 'soft' personality characteristics have become more and more important, because working environments need to be more flexible to keep up with the continuous changes and developments. This leads to changes in the personnel selection process where more and more emphasis is put on so-called soft factors like communication skills and certain personality traits (Spencer \& Spencer, 1993). Work settings are less structured and productivity is more dependent on individuals' contributions e.g. interpersonal communication and teamwork. This dependency requires different skills and competencies from people, which are not automatically learnt in the traditional educational context (Boyatzis e.a., 1995).

The question what kind of personality characteristics are important for labour market success is addressed by different research fields:

Many studies in personnel selection research have been conducted to investigate the relationships between personality and job performance (Tett et al., 1991). In these studies the personality characteristics are mainly defined in terms of the so called Big Five personality constructs. Factor analytic research revealed that these constructs (agreeableness, conscientiousness, emotional stability, extraversion and openness to experience) cover the broad domain of personality to a large extent (Barrick \& Mount, 1991; Robbins, 1996). However, others do argue that these broad personality constructs will not bring as much insight in the relationship between personality and job performance as other, more specific personality constructs will do (Van den Berg, 1992).

In labour market research, only recently the importance of more individually related characteristics for labour market functioning has been recognized. Traditionally, there are mainly two theoretical views on people's productivity on the labour market. The human capital theory (Becker, 1964) emphasizes that an individual's productivity is mainly the result of the education followed. The screening hypothesis on the other hand (Thurow, 1975) states that productivity is developed mainly during 'working on the job'. Education, in the latter view, merely reflects the trainability of an employee. However, both theories emphasize the importance of 'hard' factors, like education, but the more 'soft' factors, e.g. personal characteristics remain out of scope. Recent research attempts have been aimed at exploring the importance of these characteristics of people and point out the importance of cognitive abilities, learning skills and personality (Nijhof, 1997). However, it remains to be elaborated what kind of specific constructs are relevant for explaining labour market success.

Since personality characteristics have become an important selection device in personnel selection, the predictive efficacy of personality measures for labour market success should be evident. However, most of the empirical work is done on the relation between personality characteristics and job performance, mainly in the field of organisational studies. Only few studies address the role of personality characteristics during the transition from school to 
work. This paper is aimed at exploring the predictive efficacy of several personality characteristics on success during labour market entry. It will explore the importance of personality for labour market success in the context of more traditional hard human capital variables like study results and study field. The analyses will be conducted with a sample of graduates in Economics of Maastricht University. For these graduates data were available on four possibly relevant personality traits: Locus of control, Type A behaviour, Selfmonitoring and Sensation seeking. These traits can be considered specific personality constructs. They all have considerable validity and reliability in former research and will be addressed later on. In this paper the constructs will be used to address the following research questions: To what extent do personality characteristics predict successful labour market entry of graduates in Economics? How much weight do these effects have compared to the more traditional 'hard' factors like study results and type of education?

For defining 'successful' labour market entry, Van der Velden en Wieling (1994) have argued both chances of work and quality of the job should be considered. Several indicators are therefore used to reflect these dimensions; having a job soon after graduation, having a tenure position, having an academic job, and the wages. The predictive value of personality and other variables will be explored by logistic and linear regressions on these labour market indicators. This will be further explained in section 3, the methodology section. However, in section 2, relevant theoretical views and research will be discussed first, in order to be able to formulate some hypotheses about the predictive value of the personality constructs used. In section 4, the results of the logistic and linear regression models will be presented, and finally, in section 5 , conclusions and implications of the study will be discussed.

\section{Theoretical background}

In exploring the predictive value of personality characteristics on labour market entry success, mainly two research fields are involved; labour market research with respect to the allocation of different jobs among different people and personnel selection research with respect to work related characteristics of individuals which are desirable for employers.

In personnel selection research concern has been expressed with respect to the validity of personality measures used in personnel selection practices. Many personality measures are not work related, but are nevertheless widely used in selection processes. It has, however, been shown that a more fundamented choice of personality measures for the prediction of well-defined outcomes, increases the predictive validity of personality measures to a large extent (Van den Berg, 1992). Earlier, some extensive meta-analyses have reviewed the validity of personality measures for personnel selection and pointed out acceptable values (Barrick \& Mount, 1991; Tett, Jackson \& Rothstein, 1991). These meta-analyses reviewed all kinds of personality measures. These measures have been mainly interpreted in terms of the Big Five personality constructs (Barrick \& Mount, 1991) but include more specific constructs like Locus of control and Type A behaviour as well (Tett, Jackson \& Rothstein, 1991).

Thus, the validity of personality measures in personnel selection as such does no longer seem to be the issue, although the specific theoretical constructs to be used are still subject 2 
for discussion. However, the question rises to what extent personality measures display validity with respect to the prediction of success in labour market entry as well. In labour market research, very few empirical studies have been conducted so far with respect to the possible effect of personality on a successful transition from school to work. Education is traditionally seen as the most important selection device in labour market theories. The human capital theory states that the selection of a certain employee is based on the employee's productive skills (Becker, 1964). Education and training can in this view improve the worker's productivity. Personality characteristics only come in focus as reflecting innate productive characteristics, but do not have a role in predictive models. In the screening hypothesis on the other hand (Thurow, 1975), education is considered not to improve people's productivity in itself, but rather to reflect the desired characteristics for employers that people already possess when they enter the educational system, for example trainability and adaptability. However, existing labour market theories only provide some general ideas on why firms select certain employees (Van Beek, 1993). Personality is not considered of explicit importance in the screening hypothesis models neither.

Recent changes in labour market demand have confronted the research field with the fact that the desired characteristics of employees on today's labour market are not sufficiently covered or reflected by the 'hard' factor educational background anymore. The more 'soft' factors like communication skills and personality are of explicit importance now. These demands are already reflected in personnel selection practice, but labour market research is lagging behind.

How do these 'new' requirements relate to the traditional explanatory factors normally used in research? The purpose of this study is to answer this question by exploring the predictive value of personality constructs with respect to labour market entry indicators, next to the more traditional factors like study results. For a sample of graduates from Maastricht University, four personality traits were measured during their study and after graduation. These characteristics are: Locus of control, Type A behaviour, Self-monitoring and Sensation seeking. These traits are selected because 1) the traits are more specific than general descriptions of personality e.g. based on the Big Five, and 2) previous research has shown that these traits are relevant and predictive for behaviour in the context of work. In the following subsections (2.1 to 2.4) we briefly elaborate on these constructs and discuss their relevance for labour market success.

\section{$2.1 \quad$ Locus of control}

Locus of control refers to the individual's generalized belief in internal versus external control of reinforcements. The concept has been first introduced by Rotter (1966) in his social learning theory. He distinguished people who believe that events are uncontrollable and achievements are merely based on luck or the influence of other people, or institutions (externals) and people who believe they can influence their environment and who believe achievements do depend to a large extent on their own efforts (internals). Research conducted with this concept in relation to job functioning has concentrated on several different features, such as job satisfaction, absenteeism, job involvement and turnover 
(Spector, 1982; Blau, 1987). Generally speaking, internals seem to perform better in their jobs. However, differences between different kinds of jobs should be taken into account; internals seem to do well in complex tasks and in jobs which require initiative and independence, whereas externals seem to be better performers in structured, routine tasks and in jobs which require compliance (Robbins, 1996).

In predicting the labour market success of graduates in Economics, the general findings that internals seem to function and perform better in complex functions seems most important. On average, graduates with an academic level are expected to obtain jobs with rather complex tasks. Thus, in our view, students scoring high on internal Locus of control are expected to have a larger chance for success in labour market entry, for all labour market indicators.

\subsection{Type A behaviour}

Type A behaviour refers to a behavioural pattern characterized by being in a hurry and trying to achieve more in less time. People with Type A behaviour are characterized by impatience, hostility, a high level of competitiveness and a constant time urgency. In fact this behaviour pattern has been recognized as coronary hart disease prone behaviour and Type $A$ behaviour measures were therefore used to screen people in the context of health research (Appels, 1985; Friedman \& Rosenman, 1974). Research conducted with this concept related to job functioning has revealed that Type A's are fast workers, they emphasize quantity over quality, they make poor decisions because they make them too fast and in managerial positions these characteristics are rarely desirable to reach the top positions (Friedman \& Rosenman, 1974). However, great salespersons are often Type A's. The continuous urge for achieving more in less time seems useful in particular labour market segments. So far, for our analyses we expect a positive effect of scoring higher on Type A behaviour on the labour market indicators referring to chances, rather than for the quality of the job (academic level).

\section{$2.3 \quad$ Self-monitoring}

Self-monitoring refers to the ability of people to adapt their self-presentation to the requirements of the environment or situation. It is therefore related to the sensibility for what is considered appropriate or desirable expressive behaviour in different situations and the ability to control and alter this behaviour (Snyder, 1974). People scoring high on this trait can alter their expressive behaviour according to the social requirements while feeling quite different inside. People scoring low on this trait do behave more according to their own inner state of mind and their expressive behaviour is more in line with their own feelings and thoughts, without concerning much about what would be appropriate in a social sense. High Self-monitoring could be very useful in jobs which require different roles like managerial jobs, or which require public appearance, like sales jobs. More in general it seems that Selfmonitoring can enhance an individual's chances to obtain career success in organizations (Kilduff \& Krackhardt, 1994). Research with respect to the effect of Self-monitoring on managerial career success reveals that high self-monitors achieve more cross-company promotions and obtain more internal promotions than low scorers when they stay with the 
same employer (Kilduff \& Day, 1994). Furthermore, high self-monitors appeared to be more active in searching for information about potential employers than low self-monitors (Snyder \& Copeland, 1989). However, Blustein (1987) argued that low self-monitors do not need to gather much information to find out what kind of career they value, because they already have more self-knowledge at this point. For the purpose of this study, we expect scoring higher on Self-monitoring will have a positive effect on job chances. We don't have any specific hypothesis referring to the quality of the job since we only consider the labour market entry phase.

\section{$2.4 \quad$ Sensation seeking}

Sensation seeking refers to the motivation to experience sensation (Zuckerman, 1979a and 1991, Feij \& Van Zuilen, 1984). People scoring high on this trait are characterized by a continuous need to experience new and varied events. They therefore like the unpredictable and risky situations, whereas people scoring low on this trait prefer the more predictable and stable environments. High scorers seem to have a high level of arousal tolerance, low scorers a low level. This difference seems to have a biological base (Zuckerman, 1979a). Research with respect to this personality characteristic and job functioning has focused on job preference and job fit, but also on job performance and satisfaction. Even the job search process has been point of focus (Van den Berg, 1992). That is, Sensation seeking has been related to the ease and fastness of finding a job, indicating that high sensation seekers found a fulltime job faster than low sensation seekers (Cellini \& Lorenz, 1983). There are also signs that high sensation seeking is associated with success in higher management jobs (Franken, 1988). In this study, we therefore expect a positive effect of scoring higher on Sensation seeking on finding a job soon and no effect, or even a reversed effect on getting a tenure position.

\section{Methodology}

This study will be conducted with a sample of graduates in Economics of Maastricht University. For 137 persons we gathered personality data before graduation in the period 1993-1995 in the context of skills and training courses as part of the study programme (Boone et al., 1994). To enlarge the sample, additional personality data have been gathered after graduation for 200 graduates as well. In total, personality data were collected for 337 persons. For 42 persons personality data were available twice or even three times. This group has been used to conduct a test-retest reliability analysis with respect to the personality measures used.

Locus of control has been measured with a Dutch translation of the Rotter Locus of control scale (Rotter, 1966). Whereas the original scale contains 29 forced-choice items, the translated version contains 37 items. The difference pertains to the amount of filler-items, which are present to obscure the purpose of the test. In the Dutch translation, there are 8 filler items more. We obtained a total Locus of control score by counting the internal alternatives chosen from the forced-choice Locus of control items (0-23). Thus, high scores 
imply an internal orientation. The reliability (Cronbach's alpha) and validity of the Dutch translated version has been demonstrated with acceptable values in several studies (Boone et al., 1994; 1990; Boone, 1992; De Brabander et al., 1992). The test-retest reliability in our sub-sample is only $0.61(n=42)$, which is acceptable.

Type A behaviour has been measured by a Dutch adaption of the original Jenkins Activity Survey (JAS) (Appels, 1985). The adapted version contains 24 items with some response categories being indicative of Type A behaviour, and others not. The indicative responses are valued with score 1 , the others with score 0 , implying a total score ranging from 0-24. The Dutch JAS reveals satisfactory reliability (Cronbach's alpha) and validity (Appels, 1985). The test-restest reliability in our sub-sample is $0.65(n=42)$.

Self-monitoring has been measured by a Dutch translation of the 18-item Self-monitoring scale (Snyder \& Gangestad, 1986). Respondents are asked to consider the 18 statements as true or false (forced choice) in their opinion. In fact, there are no true or false answers. The total score can be obtained by counting the high Self-monitoring answers (0-18). Validity has been demonstrated to be sufficient (Boone et al., 1994; Snyder \& Gangestad, 1986). Test-retest reliabilty within our sub-sample is however low $(0.57, \mathrm{n}=42)$. Taking into account the small number of cases in the sub-sample we decided nevertheless to accept this instrument.

Sensation seeking has been measured with the so-called 'Spanningsbehoeftelijst' (SBL), developed by Feij and Van Zuilen (1984). This is a Dutch translation of the American Sensation Seeking Scale (Zuckerman, 1979). The SBL consists of 51 Sensation seeking items and 16 filler items, for which respondents have to indicate on a five-point scale to what extent they (dis)agree with the statements. The composite total Sensation seeking score can be obtained by counting the scores for the individual items. Reliability (Cronbach's alpha) and validity of the scale have been demonstrated to be satisfactory (Boone et al., 1994; Feij \& Van Zuilen, 1984). Test-retest reliability within our sub-sample appeared to be 0.82 ( $\mathrm{n}=$ 41) which is even high.

We obtained labour market entry data from a survey sent to all graduates a year and a half after graduation. In this survey all kinds of information with respect to the search process, the labour market position and other activities are asked. This research activity takes place on a regular base by the Research Centre for Education and the Labour Market (Dutch shortcut: ROA) and studies are reported every year on the subsequent cohorts of Maastricht University (see Ramaekers and Ramaekers \& Welters, 1996-1998). For the purpose of our study the 1994-1996 waves are used. These waves contain most of the graduates for whom personality data are available. The sample for this study hereby amounted to a maximum of 204 persons for whom analyses can be applied. Four indicators of successful labour market entry are used as dependent variables. These indicators pertain to job chances and quality of work. They have been found to be reliable indicators for labour market success (Van der Velden \& Wieling, 1994). 
The dependents are:

- having a job within three months after graduation;

- having a tenure position;

- having a job for which an academic degree is required;

- gross monthly wages.

Next to the personality measures, relevant covariates were considered for their effect on labour market entry. By using administrative data for all graduates, the following covariates have been taken on board:

- gender male (dummy);

- age;

- study field: Organization/Marketing versus Accounting/Finance versus other study fields (dummy's);

- mean study results during the last two years of the study programme;

- final thesis result;

- managerial experience;

- working experience.

For the purpose of this study the personality data gathered during the study programme are most valuable $(n=137)$, because in predicting labour market success during the entry phase, the personality data should be gathered in advance to be sure that the direction of any association goes from personality to labour market success. However, to increase the sample size, we decided to supplement the sample of 'old' personality data with additional data gathered after graduation when pre-graduation personality data were not available. Subsequently, the analyses with respect to the effects on labour market success have been controlled for old and new cases by using dummy variables indicating old and new cases for all variables in the analysis. No significant differences were found in the estimated effects of personality for old cases and new cases for the outcome variables used in this study. Therefore, only the results of the analyses with the complemented sample will be reported $(n=204)$.

The conceptual relationship between personality and labour market outcomes for this study is displayed in figure 1.

As can be seen from figure 1, personality can have both a direct and an indirect effect on labour market outcomes. The direct effect of personality on labour market outcomes represents the effect after controlling for other relevant variables like schooling. This is the sort of effect which was addressed in the previous section. However, the importance of personality may well be underestimated if we only look at the direct effects. Personality traits may also have a significant effect on learning outcomes, which in turn affect the labour market outcomes. Therefore we would also like to consider the total effect of personality, 
that is the sum of direct and indirect effects.

Figure 1: Conceptual relationship between personality and labour market outcomes

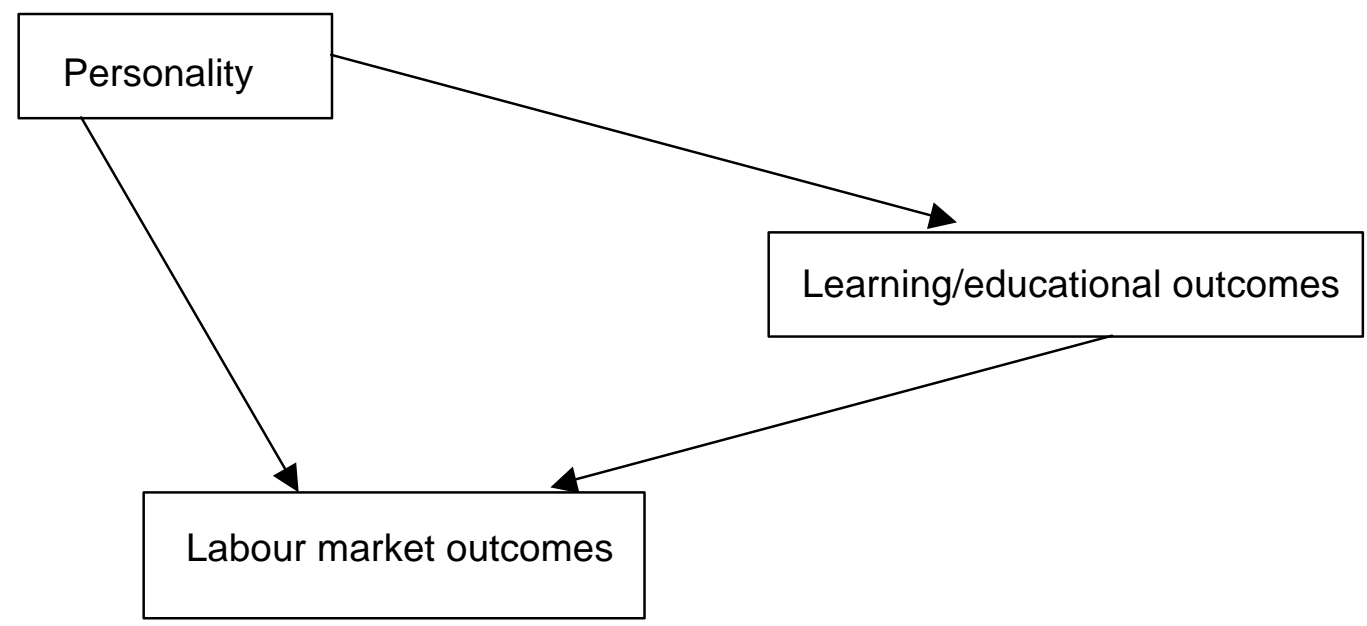

The analyses with the complemented sample will therefore be conducted within a two-step model: in the first step only the personality data and the covariates gender and age are included. In this way, the first-step model analyses the total effect of personality. In the second step, the educational variables are introduced into the model. These refer to study field, study results and study length, as well as to managerial experience and working experience. In this way, the second-step model analyses the direct effect of personality controlled for study results and other traditional human capital variables.

In the next section the results of the two-step logistic and normal linear regression analyses will be presented.

\section{Results}

First of all, descriptives and plots were analysed for outliers and normality. All interval variables show a near normal distribution. Descriptive data and Pearson's correlations of the data are presented in the appendix.

In table 1 the results of the logistic regression analyses with respect to the first labour market indicator are presented; the effects of personality characteristics on the chance of having a job within three months after graduation.

As can be seen from table 1, only the second model differs significantly from the base model. Scoring high on the (internal) Locus of control scale has a positive effect on the chance of having a job within three months. No effects are found for other personality characteristics. For the traditional human capital covariates, only study field, especially the finance or accounting specialization, is found to have a strong positive effect on the chance of having a job within three months. 
Table 1

Regression estimates of the effects of personality on having a job within three months

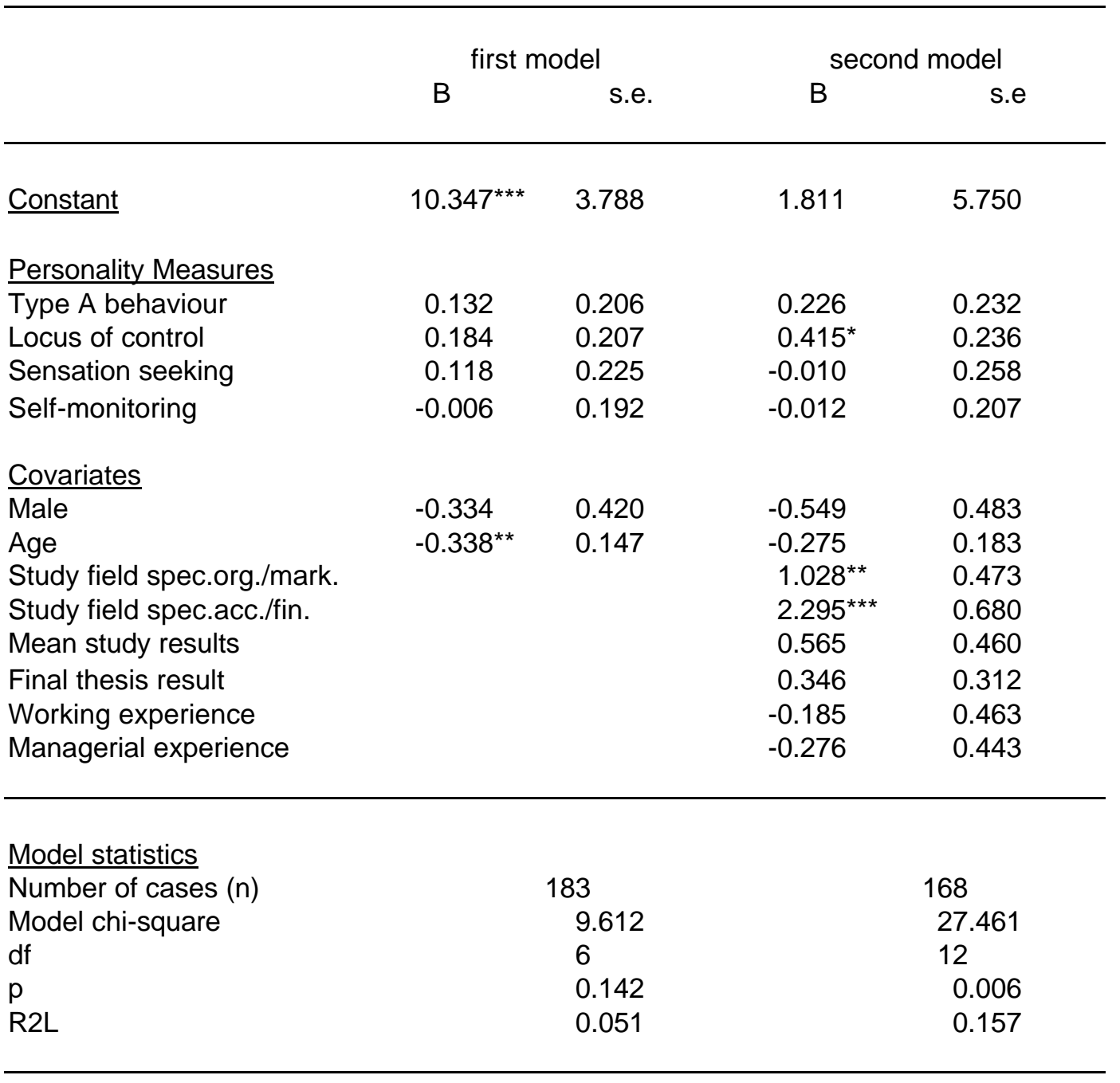

* significant at $0.10,{ }^{* *}$ significant at 0.05 and ${ }^{* * *}$ significant at 0.01

In the next analysis, the chance of having tenure is explored. Table 2 presents the results.

None of the models differs significantly from the base model. The $R^{2}$ statistic indicates poor predictive efficacy as well for both of them. Nevertheless, both Type A behaviour and (internal) Locus of control have a positive effect on the chance of having tenure. The effect of Locus of control is only present in the second model, in which mean study results show a positive effect on the chance of having tenure as well. Type A behaviour shows a stable positive effect in both models. The effects of personality and mean study results thus appear to be independent. For all other variables, no effects are found.

The next indicator for success in labour market entry that will be considered is having an academic job. Table 3 presents the results of the analyses. 
Table 2

Regression estimates of the effects of personality on having a tenure position

\begin{tabular}{|c|c|c|c|c|}
\hline & \multicolumn{2}{|c|}{ first model } & \multicolumn{2}{|c|}{ second model } \\
\hline & B & s.e. & B & s.e \\
\hline$\underline{\text { Constant }}$ & 1.102 & 3.329 & -2.336 & 5.023 \\
\hline \multicolumn{5}{|l|}{ Personality Measures } \\
\hline Type A behaviour & $0.382^{\star \star}$ & 0.190 & $0.507^{\star *}$ & 0.206 \\
\hline Locus of control & 0.246 & 0.186 & $0.379^{*}$ & 0.214 \\
\hline Sensation seeking & -0.071 & 0.196 & -0.213 & 0.220 \\
\hline Self-monitoring & 0.038 & 0.171 & -0.037 & 0.185 \\
\hline \multicolumn{5}{|l|}{ Covariates } \\
\hline$\overline{\text { Male }}$ & 0.077 & 0.353 & 0.136 & 0.396 \\
\hline Age & -0.024 & 0.130 & -0.077 & 0.153 \\
\hline Study field spec.org./mark. & & & 0.120 & 0.454 \\
\hline Study field spec.acc./fin. & & & 0.792 & 0.534 \\
\hline Mean study results & & & $0.788^{* *}$ & 0.397 \\
\hline Final thesis result & & & -0.138 & 0.270 \\
\hline Working experience & & & 0.277 & 0.374 \\
\hline Managerial experience & & & 0.058 & 0.374 \\
\hline \multicolumn{5}{|l|}{ Model Statistics } \\
\hline Number of cases $(n)$ & & 172 & & 157 \\
\hline Model chi-square & & 6.664 & & 17.086 \\
\hline df & & 6 & & 12 \\
\hline $\mathrm{p}$ & & 0.353 & & 0.146 \\
\hline $\mathrm{R} 2 \mathrm{~L}$ & & 0.029 & & 0.083 \\
\hline
\end{tabular}

${ }^{*}$ significant at $0.10,{ }^{* *}$ significant at 0.05 and ${ }^{* * *}$ significant at 0.01

As can be seen from table 3 , none of the two models tested differs significantly from the base model, just as in the analyses with respect to having tenure. The results show there are no effects of personality characteristics. Study results do matter though; the final thesis result has a positive effect on the odds of having an academic job. Managerial experience appears to have a positive effect as well. Thus, for this labour market indicator, only the traditional 'hard' human capital variables have predictive value.

In the last analyses the effects of personality characteristics are considered on gross monthly wages. Table 4 presents the results. People who are working on a Ph.D. thesis are left out of the analysis because of their regulated small wages. 
Table 3

Regression estimates of the effects of personality on having an academic job

\begin{tabular}{|c|c|c|c|c|}
\hline & \multicolumn{2}{|c|}{ first model } & \multicolumn{2}{|c|}{ second model } \\
\hline & B & s.e. & B & s.e \\
\hline Constant & 4.398 & 3.263 & -2.214 & 4.835 \\
\hline \multicolumn{5}{|l|}{ Personality Measures } \\
\hline Type A behaviour & 0.175 & 0.179 & 0.126 & 0.193 \\
\hline Locus of control & 0.199 & 0.180 & 0.220 & 0.204 \\
\hline Sensation seeking & 0.198 & 0.192 & 0.065 & 0.212 \\
\hline Self-monitoring & -0.093 & 0.167 & -0.061 & 0.182 \\
\hline \multicolumn{5}{|l|}{ Covariates } \\
\hline Male & 0.117 & 0.341 & 0.134 & 0.382 \\
\hline Age & -0.177 & 0.128 & -0.113 & 0.147 \\
\hline Study field spec.org./mark. & & & 0.408 & 0.453 \\
\hline Study field spec.acc./fin. & & & 0.405 & 0.514 \\
\hline Mean study results & & & 0.100 & 0.375 \\
\hline Final thesis result & & & $0.494^{*}$ & 0.267 \\
\hline Working experience & & & -0.189 & 0.359 \\
\hline Managerial experience & & & $0.632^{*}$ & 0.362 \\
\hline \multicolumn{5}{|l|}{ Model Statistics } \\
\hline Number of cases $(n)$ & & 172 & & 156 \\
\hline Model chi-square & & 6.650 & & 14.384 \\
\hline df & & 6 & & 12 \\
\hline$p$ & & 0.354 & & 0.277 \\
\hline R2L & & 0.028 & & 0.067 \\
\hline
\end{tabular}

${ }^{*}$ significant at $0.10,{ }^{* *}$ significant at 0.05 and ${ }^{* * *}$ significant at 0.01

As can be seen from table 4, both models differ significantly from the base model. With respect to the effects of personality characteristics, only Type A behaviour appears to make a difference; a positive effect is present in both models. For the other personality characteristics no effects are found. Study field organization/marketing negatively affects wages, when introduced into the model. Mean study results appear to have a positive effect on wages. The effect of Type A behaviour remains rather stable, when the traditional human capital variables are introduced into the analysis, meaning that the effect of this 'soft' factor is independent from the other 'hard' human capital factors.

In the following and last section, the results of this explorative study will be discussed and interpreted. 
Table 4

Regression estimates of the effects of personality on gross monthly wages

\begin{tabular}{|c|c|c|c|c|}
\hline & \multicolumn{2}{|c|}{ first model } & \multicolumn{2}{|c|}{ second model } \\
\hline & B & s.e. & $\mathrm{B}$ & s.e \\
\hline Constant & $8.108^{\star * \star}$ & 0.355 & $7.431^{* * *}$ & 0.500 \\
\hline \multicolumn{5}{|l|}{ Personality Measures } \\
\hline Type A behaviour & $0.084^{* * *}$ & 0.020 & $0.079^{\star * *}$ & 0.020 \\
\hline Locus of control & 0.031 & 0.020 & 0.025 & 0.021 \\
\hline Sensation seeking & 0.001 & 0.022 & -0.002 & 0.023 \\
\hline Self-monitoring & -0.007 & 0.018 & -0.003 & 0.018 \\
\hline \multicolumn{5}{|l|}{ Covariates } \\
\hline Male & 0.007 & 0.038 & -0.009 & 0.039 \\
\hline Age & 0.005 & 0.014 & 0.017 & 0.015 \\
\hline Study Field spec.org./mark. & & & $-0.076^{*}$ & 0.045 \\
\hline Study Field spec.acc./fin. & & & -0.034 & 0.051 \\
\hline Mean Study Results & & & $0.072^{*}$ & 0.040 \\
\hline Final Thesis Result & & & 0.010 & 0.026 \\
\hline Working Experience & & & 0.006 & 0.036 \\
\hline Managerial Experience & & & 0.037 & 0.037 \\
\hline \multicolumn{5}{|l|}{ Model Statistics } \\
\hline Number of cases $(n)$ & & 164 & & 150 \\
\hline Adj. R & & 0.101 & & 0.109 \\
\hline $\mathrm{F}$ & & 4.040 & & 2.517 \\
\hline $\mathrm{p}$ & & 0.001 & & 0.005 \\
\hline
\end{tabular}

Note 1: one case, representing an individual who is working at a dissertation, is excluded from analysis

Note 2: * significant at $0.10,{ }^{* *}$ significant at 0.05 and ${ }^{* * *}$ significant at 0.01

\section{Conclusions and considerations}

In this study the value of personality characteristics has been explored for predicting success in labour market entry. For two out of the four personality constructs used in the analyses, e.g. the (internal) Locus of control construct and Type A behaviour, positive effects have been found for several indicators of successful labour market entry. These are interesting findings because the effects of personality appear to be independent from the effects of study results and other traditional human capital factors. This means personality has a right of its own, and is not merely reflected by other 'hard' factors. Both kinds of human capital variables seem to lead to returns on the labour market. 
Study results and other human capital factors are traditionally widely considered to be used as a selection device by employers. The results of this study underline the explicit importance of personality characteristics for a successful labour market entry as well. This is in line with nowadays job selection practices, where personality characteristics already are an important topic.

In this study, the Locus of control construct affects the fastness of finding a job and having tenure, while Type A behaviour affects having tenure and wage level. Traditional human capital factors seem to affect chances of getting a job and the quality of the job as well. For one specific quality indicator, i.e. obtaining an academic job, the traditional human capital factors 'final thesis result' and 'managerial experience' are of predictive value, while personality has no effect at all. Since in our sample approximately (only) half of the graduates obtained an academic job, the human capital factors show their own important selection value.

Although the study is explorative in nature, it shows the importance of integrating psychological concepts into labour market studies. The theoretical link between the personality constructs used in this study and labour market success deserves some critical consideration, however. The personality constructs under consideration have been used to predict rather general indicators of labour market success. It may be useful to consider (other) personality characteristics and job characteristics from a matching point of view, and to take more organizational related characteristics into account. Furthermore, only short term labour market success has been explored in this study. It would be interesting to know more about the effects of replication of the study on long term labour market success as well.

Finally, this study is conducted with a sample of graduates in economics of Maastricht University. The findings can therefore not be simply generalized to other graduates. Replication of the study with other samples of graduates would be appropriate.

\section{References}

Appels, A. (1985), De Jenkins Activity Survey. Swets \& Zeitlinger: Lisse.

Barrick, M.R. \& Mount, M.K. (1991), The Big Five personality dimensions and job performance: a meta-analysis. Personnel Psychology, 44, 1-26.

Becker, G.S. (1964), Human Capital. New York: NBER.

Beek, van, K.W.H. (1993), To be hired or not to be hired, the employer decides; relative chances of unemployed job-seekers on the Dutch labor market. Universiteit Amsterdam.

Berg, van den, P.T. (1992), Persoonlijkheid en Werkbeleving: de validiteit van persoonlijheidsvragenlijsten, in het bijzonder die van een spanningsbehoeftelijst. Centrale Huisdrukkerij VU, Amsterdam.

Blau, G.J. (1987), Locus of control as a potential moderator of the turnover process. Journal of Occupational Psychology, 60, 21-29. 
Blustein, D.L. (1987), Social cognitive orientations and career development: a theoretical and empirical analysis. Journal of Vocational Behavior, 31, 63-80.

Boone, C., De Brabander, B., Gerits, P. \& Willeme, P. (1990), Relation of scores on Rotter's I-E scale to short-term and Inog-term control expectancies and fatalism. Psychological Reports, 66, 11071111.

Boone, C. (1992), Onderzoek naar het verband tussen de perceptie van controle van bedrijfsleiders en de strategie en de resultaten van ondernemingen in de meubelindustrie. Unpublished doctoral dissertation, University of Antwerp, Antwerp.

Boone, C., De Brabander, B. \& Van Witteloostuijn, A. (1999), The impact of personality on behavior in five prisoner's dilemma games. Journal of Economic Psychology, 20, 343-377.

Boyatzis, R.E., Cowen, S.S., Kolb, D.A. and associates (1995), Innovation in Professional Education. Steps on a journey from teaching to learning; the story of change \& invention at the Weatherhead School of Management. Jossey-Bass Publishers, San Francisco.

Cellini, H.R. \& Lorenz, J.R. (1983), Job club group training with unemployed offenders. Federal Probation, 46, 46-50.

De Brabander, B., Boone, C. \& Gerits, P. (1992), Locus of control and cerebral asymmetry. Perceptual \& Motor Skills, 75, 131-143.

Feij, J.A. \& Van Zuilen, R.W. (1984), Handleiding bij de spanningsbehoeftelijst (SBL). Swets \& Zeitlinger, Lisse.

Franken, R.E. (1988), Sensation seeking, decision making styles, and preference for individual responsibility. Personality and Individual Differences, 9, 139-146.

Friedman, M. \& Rosenman, R.H. (1974), Type A behavior and Your Hart. Knopf, New York.

Hogan, R., Hogan, J. \& Roberts, B.W. (1996), Personality measurement and employment decisions. Questions and answers. American Psychologist, 51, 469-477.

Kilduff, M. \& Day, D.V. (1994), Do chameleons get ahead? The effects of Self-monitoring on managerial careers. Academy of Management Journal, 37, 1047-1060.

Kilduff, M. \& Krackhardt, D. (1994), Bringing the individual back in: a structural analysis of the internal market for reputation in organizations. Academy of Management Journal, 37, 87-108.

Nijhof, W.J. (1998), Qualifying for the future. In: Nijhof, W.J. \& Streumer, J.N. (eds.). Key Qualifications in Work and Education. Kluwer Academic Publishers, Dordrecht.

Ramaekers, G.W.M. (1996), WO-scanner economie 1995. Basismeting cohort '94. ROA-R-1996/15. Research Centrum voor Onderwijs en Arbeidsmarkt, Maastricht.

Ramaekers, G.W.M. (1997), WO-Monitor economie 1996. Basismeting cohort '95. ROA-R-1997/4. Research Centrum voor Onderwijs en Arbeidsmarkt, Maastricht.

Ramaekers, G.W.M. \& Welters, R.A.M.H.M. (1998), Start van de loopbaan na de Universiteit Maastricht 1996-1997. ROA-R-1998/7. Research Centrum voor Onderwijs en Arbeidsmarkt, Maastricht.

Rotter, J.B. (1966), Generalized expectancies for internal versus external control of reinforcement. Psychological Monographs, 80, No. 609. 
Smith, M. \& George, D. (1994), Selection Methods. In: Cooper, G.L. \& Robertson, I.T. (eds.). Key Reviews in Managerial Psychology; concepts and research for practice. John Wiley \& Sons Ltd, England.

Snyder, M. (1974), Self-monitoring of expressive behavior. Journal of Personality and Social Psychology, 30, 526-537.

Snyder, M. \& Gangestad, S. (1986), On the nature of Self-monitoring: matters of assessment, matters of validity. Journal of Personality and Social Psychology, 51, 125-139.

Snyder, M. \& Copeland, J. (1989), Self-monitoring processes in organizational settings. In: Giacalone, R.A. \& Rosenfeld, P. (eds.). Impression management in the organization. Erlbaum, Hillsdale, New York, 7-19.

Spector, P.E. (1982), Behavior in organizations as a function of employee's Locus of control. Psychological Bulletin, 91, 482-497.

Spencer, L.M. \& Spencer, S.M. (1993), Competence at work: models for superior performance. John Wiley \& Sons, Inc., United States of America.

Tett, R.P., Jackson, D.N. \& Rothstein, M. (1991), Personality measures as predictors of job performance: a meta-analytic review. Personnel Psychology, 44, 703-742.

Thurow, L. C. (1975), Generating Inequality. New York: Basic Books.

Van der Velden \& Wieling (1994), De arbeidsmarktkansen per opleiding. In: Scholten, H. \& De Groot, S.C. (eds.). Arbeidsmarkt en Sociale Zekerheid, Beleid en Beweging. IVA Tilburg / Eburon Delft, 106-114.

Zuckerman, M. (1979a), Sensation seeking: beyond the optimal level of arousal. Lawrence Erlbaum, Hillsdale, New York.

Zuckerman, M. (1979b), Sensation seeking and risk taking. In: Izard, C.E. (ed.). Emotions in personality and psychopathology. Plenum Press, New York, 163-197.

Zuckerman, M. (1991), Psychobiology of personality. Cambridge University Press, Cambridge, MA. 


\section{Appendix}

As can be seen from table A, a large majority of the sample found a job within three months after graduation (78\%). Of all graduates in our sample $63 \%$ has a tenure position at the date of the survey, whereas $49 \%$ has an academic job. The gross monthly wages are 3.847 Dutch guilders on average. There are more males than females in this study (males $58 \%$ ) and the average age is about 26 years at the time of the labour market survey. Of all graduates $47.6 \%$ have studied the organizational or marketing specialization within the Business Administration or International Management study and $27.4 \%$ the finance or accounting specialization. The remaining about $26 \%$ have studied a different subject within these economical studies. During study $47 \%$ have gained working experience and $61 \%$ some managerial experience. In table $\mathrm{B}$, the correlations between the covariates are displayed apart from the correlations between the independents and the dependents with the covariates in table $A$. 
Table A

Descriptive statistics and Pearson's correlations

\begin{tabular}{|c|c|c|c|c|c|c|c|c|c|c|c|c|}
\hline \multirow{2}{*}{ Variables } & & \multirow[b]{2}{*}{ Mean } & \multirow[b]{2}{*}{ SD } & \multirow[b]{2}{*}{$\mathrm{N}$} & \multirow[b]{2}{*}{$(1)$} & \multirow[b]{2}{*}{$(2)$} & \multirow[b]{2}{*}{ (3) } & \multicolumn{2}{|c|}{ Correlations } & \multirow[b]{2}{*}{$(6)$} & \multirow[b]{2}{*}{$(7)$} & \multirow[b]{2}{*}{ (8) } \\
\hline & & & & & & & & $(4)$ & $(5)$ & & & \\
\hline \multicolumn{13}{|c|}{ Indicators of Labour Market Success } \\
\hline \multicolumn{13}{|c|}{ (1) Being unemployed less than three } \\
\hline (2) Having a tenure pos & & $\begin{array}{l}0.180 \\
0.630\end{array}$ & $\begin{array}{l}0.420 \\
0.480\end{array}$ & $\begin{array}{l}199 \\
185\end{array}$ & $0.189^{* *}$ & - & - & - & - & - & - & $\begin{array}{l}- \\
-\end{array}$ \\
\hline \multicolumn{13}{|c|}{ (3) Having a job requiring an academic } \\
\hline degree & & 0.490 & 0.500 & 186 & $0.187^{\star \star}$ & -0.028 & - & - & - & - & - & - \\
\hline \multicolumn{2}{|c|}{ (4) Gross monthly wages (log) } & 8.255 & 0.237 & 177 & $0.274^{* * *}$ & $0.375^{\star \star *}$ & $0.229^{\star * \star}$ & - & - & - & - & - \\
\hline Personality Measures & score range & & & & & & & & & & & \\
\hline (5) Type A behaviour & $0-24$ & 13.840 & 4.100 & 194 & 0.073 & $0.161^{* *}$ & 0.109 & $0.335^{\star \star \star}$ & - & - & - & - \\
\hline (6) Locus of control & $0-23$ & 12.603 & 3.720 & 194 & 0.072 & 0.122 & 0.096 & $0.135^{\star}$ & 0.084 & - & - & - \\
\hline (7) Sensation seeking & $0-51$ & 12.185 & 1.656 & 195 & 0.023 & 0.087 & 0.107 & $0.148^{*}$ & $0.269^{* * *}$ & $0.370^{\star * *}$ & - & - \\
\hline (8) Self-monitoring & $0-18$ & 9.323 & 3.082 & 198 & 0.001 & 0.058 & 0.033 & 0.049 & $0.299^{\star *}$ & 0.108 & $0.299^{* * *}$ & - \\
\hline \multicolumn{13}{|l|}{ Covariates } \\
\hline$\overline{\text { Male }}$ & & 0.580 & 0.500 & 204 & $-0.147^{\star *}$ & -0.018 & 0.014 & -0.021 & $-0.138^{*}$ & 0.115 & $0.194^{\star * *}$ & $0.118^{*}$ \\
\hline Age & & 25.860 & 1.260 & 204 & $-0.209^{* * *}$ & -0.005 & -0.087 & 0.044 & -0.023 & 0.042 & 0.114 & -0.037 \\
\hline Mean study results & & 6.759 & 0.515 & 202 & $0.173^{\star \star}$ & 0.117 & $0.135^{\star}$ & 0.121 & -0.014 & $0.175^{\star *}$ & 0.038 & -0.034 \\
\hline Final thesis result & & 7.347 & 0.756 & 199 & $0.119^{*}$ & 0.026 & $0.169^{* *}$ & 0.040 & 0.076 & 0.086 & 0.113 & 0.060 \\
\hline Study field spec.org./m & & 0.467 & 0.500 & 197 & 0.048 & -0.037 & 0.024 & -0.087 & 0.057 & 0.027 & 0.075 & 0.031 \\
\hline Study field spec.fin./ac & & 0.274 & 0.447 & 197 & $0.192^{\star \star \star}$ & 0.093 & -0.010 & -0.005 & 0.011 & $-0.156^{\star *}$ & -0.106 & -0.057 \\
\hline Study field otherwise ( $r$ & erence group) & 0.259 & 0.439 & 197 & $-0.251^{\star * *}$ & -0.056 & -0.017 & 0.106 & -0.077 & $0.132^{*}$ & 0.024 & 0.024 \\
\hline Working experience & & 0.470 & 0.500 & 197 & 0.009 & 0.071 & 0.045 & 0.049 & 0.116 & 0.120 & 0.090 & 0.040 \\
\hline Managerial experience & & 0.610 & 0.490 & 197 & -0.008 & 0.022 & $0.182^{\star \star}$ & $0.144^{*}$ & $0.141^{*}$ & $0.135^{\star}$ & $0.246^{\star * *}$ & 0.094 \\
\hline
\end{tabular}

Note $1:{ }^{*}$ correlation significant at the 0.1 level, ${ }^{* *}$ correlation significant at the 0.05 level and ${ }^{* *}$ correlation significant at the 0.01 level 
Table $B$

Descriptive statistics and Pearson's correlations of covariates

\begin{tabular}{|c|c|c|c|c|c|c|c|c|c|c|c|}
\hline Variables & Mean & SD & $\mathrm{N}$ & $(1)$ & $(2)$ & (3) & $\begin{array}{l}\text { Correla } \\
\text { (4) }\end{array}$ & $\begin{array}{l}\text { tions } \\
\qquad(5)\end{array}$ & $(6)$ & $(7)$ & $(8)$ \\
\hline \multicolumn{12}{|l|}{ Covariates } \\
\hline (1) Male & 0.580 & 0.500 & 204 & & & & & & & & \\
\hline (2) Age & 25.860 & 1.260 & 204 & $0.282^{* * *}$ & & & & & & & \\
\hline (3) Study field spec.org./mark. & 0.467 & 0.500 & 197 & -0.097 & 0.086 & & & & & & \\
\hline $\begin{array}{l}\text { (4) Study field spec.fin./acc. } \\
\text { (5) Study field otherwise (reference }\end{array}$ & 0.274 & 0.447 & 197 & 0.034 & $-0.191^{* * *}$ & $-0.575^{\star \star \star}$ & & & & & \\
\hline group) & 0.259 & 0.439 & 197 & 0.076 & 0.096 & $-0.553^{\star * *}$ & $-0.363^{\star * *}$ & & & & \\
\hline (6) Working experience & 0.470 & 0.500 & 197 & -0.068 & $0.174^{\star *}$ & 0.005 & -0.006 & 0.001 & & & \\
\hline (7) Managerial experience & 0.610 & 0.490 & 197 & 0.025 & -0.039 & 0.024 & -0.026 & -0.001 & $0.157^{* *}$ & & \\
\hline (8) Mean study results & 6.759 & 0.515 & 202 & -0.040 & -0.112 & 0.082 & -0.058 & -0.034 & 0.114 & 0.080 & \\
\hline (9) Final thesis result & 7.347 & 0.756 & 199 & 0.019 & $-0.120^{*}$ & 0.019 & -0.046 & 0.025 & 0.032 & 0.076 & $0.383^{* * *}$ \\
\hline
\end{tabular}

Note: ${ }^{*}$ correlation significant at the 0.1 level, ${ }^{* *}$ correlation significant at the 0.05 level and ${ }^{* * *}$ correlation significant at the 0.01 level 